\title{
Borrowing and Loan Words: The Lemmatizing of Newly Acquired Lexical Items in Sesotho sa Leboa*
}

\author{
V.M. Mojela, Sesotho sa Leboa National Lexicography Unit, University of \\ Limpopo, Turfloop Campus, Polokwane, South Africa (mojelav@ul.ac.za)
}

\begin{abstract}
The influence of foreign languages in Sesotho sa Leboa, or Northern Sotho, results in borrowing, which ultimately leads to an increase in the vocabulary of Sesotho sa Leboa. The languages influencing developments in the vocabulary of Sesotho sa Leboa include, inter alia, English, Afrikaans, Xitsonga, Tshivenda and the Nguni languages. This article aims to give a critical analysis of the advantages and disadvantages of the adoption of foreign lexical items in the lemmatization of vocabulary in Sesotho sa Leboa dictionaries. Most puristic inclined academics and intellectuals are reluctant to adopt loan words as a means of developing the Sesotho sa Leboa vocabulary. When confronted with borrowing, the purists usually prefer coinage, using indigenous lexical items to name foreign concepts. This is disadvantageous to the development of the vocabulary of the language because (1) there is no increase in the number of the lexical items in the language since only the meanings of the foreign lexical item are added to existing indigenous lexical items, and (2) in most cases, previously adopted loan words are mistaken for indigenous lexical items and given preference to newly acquired lexical items which have direct and accurate bearing on the meaning of the newly discovered or designed concepts or objects.
\end{abstract}

Keywords: BORROWING, LOAN WORDS, LEXICAL ITEMS, FOREIGN ACQUISITION, FOREIGN WORDS, COINAGE, COINED LEXICAL ITEMS, PURISM, STANDARD LANGUAGE, STANDARDIZATION, LEMMATIZATION, DEVELOPED LANGUAGES, CORPORA

Opsomming: Ontlening en leenwoorde: Die lemmatisering van nuutverworwe leksikale items in Sesotho sa Leboa. Die invloed van vreemde tale op Sesotho sa Leboa, of Noord-Sotho, het ontlening tot gevolg, wat uiteindelik lei tot ' $n$ toename in die woordeskat van Sesotho sa Leboa. Die tale wat ontwikkelinge in die woordeskat van Sesotho sa Leboa beïnvloed, sluit onder andere Engels, Afrikaans, Xitsonga, Tsivenda en die Ngunitale in. Die doel van hierdie artikel is om ' $n$ kritiese ontleding van die voordele en nadele van die oorneem van vreemde leksikale items by die lemmatisering van die woordeskat in woordeboeke van Sesotho sa Leboa te gee. Die meeste puristies gesinde akademici en intellektuele is onwillig om leenwoorde oor te neem as 'n manier om die woordeskat van Sesotho sa Leboa te ontwikkel. Wanneer hulle met ontlening gekonfronteer word, verkies puriste gewoonlik nuutskeppinge deur gebruikmaking van

An earlier version of this article was presented as a paper at the Thirteenth International Conference of the African Association for Lexicography, organized by the Bureau of the Woordeboek van die Afrikaanse Taal, Stellenbosch, South Africa, 1-3 July 2008. 
inheemse leksikale items om vreemde konsepte te benoem. Dit is nadelig vir die ontwikkeling van die woordeskat van die taal omdat (1) daar geen toename in die aantal leksikale items is nie aangesien slegs die betekenisse van die vreemde leksikale items tot die bestaande inheemse leksikale items toegevoeg word, en (2) in die meeste gevalle voorheen oorgeneemde leenwoorde aangesien word vir inheemse leksikale items en daaraan voorkeur gegee word bo nuutverworwe leksikale items wat 'n direkte en presiese verband met die betekenis van die nuutontdekte of -ontwerpte konsepte of objekte het.

Sleutelwoorde: ONTLENING, LEENWOORDE, LEKSIKALE ITEMS, VREEMDE AANWINSTE, VREEMDE WOORDE, NUUTSKEPPING, NUUTGESKEPTE LEKSIKALE ITEMS, PURISME, STANDAARDTAAL, STANDAARDISERING, LEMMATISERING, ONTWIKKELDE TALE, KORPUSSE

\section{Introduction}

When compared to most of the highly developed European languages like English and some of the highly advanced African languages such as Kiswahili, Sesotho sa Leboa is still a quite underdeveloped language as far as its lexicon is concerned. Almost all these advanced languages use loan words to develop their vocabulary. English, for instance, absorbs large numbers of foreign words, and this is one of the reasons why the corpora for many indigenous African languages will never be able to compete with the English corpus because its growth rate is always higher and faster than that of most of the African languages. This is due to its rate of acquiring new terminology through borrowing or foreign acquisition. English, for instance, is spoken in many countries on all five continents and is, therefore, able to acquire vocabulary from many languages worldwide. This is coupled with the readiness and the ability of the language to acquire new terminology through borrowing, instead of following the puristic policies.

\section{What is borrowing?}

Foreign acquisition through borrowing is the adoption of foreign lexical items in a language to refer to new concepts which originated in foreign cultures or foreign languages. Mojela (1991: 12) says:

When people of varied cultures come into contact, they have many things to share and these result in the process of foreign acquisition and an extensive increase in vocabulary. An increase in vocabulary is at the same time accompanied by an increase in meaning.

Gumperz (1968: 223) also alleges the following with regard to borrowing:

Whenever two or more speech communities maintain a prolonged contact within a broad field of communication, there are cross-currents of diffusion. 
Borrowing of lexical items from foreign languages occurs directly or indirectly. Mojela (1991: 13) describes direct borrowing in Sesotho sa Leboa as follows:

Words are borrowed from foreign languages and are incorporated into the linguistic system of Northern Sotho.

Direct borrowing results in the formation of loan words, which are subjected to the phonological system of the borrowing language. Higa (1980: 285) emphasizes this fact as follows:

When words are borrowed by one language from another, they are subjected to the phonological rules of the language that borrows.

Indirect borrowing usually occurs through coinage where only the meaning, or the sense of the foreign term is taken, and not the word itself. According to Mojela (1991: 19):

Indirect borrowing is found where a foreign or a new concept is taken over, and not the word itself. In most cases such a concept is associated with an indigenous word. This type of borrowing usually leads to the formation of polysemous words. The word which previously referred to a known concept in Northern Sotho has its meaning extended to refer, also, to the new concept which has closer affinity with the known concept.

These coined words only came into existence after the Sesotho sa Leboa speakers were introduced to these new concepts.

The following are some examples of loan lexical items adopted through direct borrowing, and their coined counterparts, the last two examples being cases of indirect borrowing where existing lexical items have been given extended meanings:

Loan word: malekere 'sweets' (from Afrikaans lekkers)

Coined word: dimonamonane (formed by the reduplication of mona 'suck' and the diminutive suffix (a)ne to express intensity)

Loan word: radio 'radio'

Coined word: seyalemoya (meaning literally 'that which goes with the wind')

Loan word: mpete 'bed'

Coined word: bolao 'place to sleep' > 'bed'

Loan word: tšhinkamo 'chewing gum'

Coined word: motu 'resin' > 'chewing gum'

Foreign acquisition through coinage is usually manifested through the semantic extensions of related indigenous lexical items to include the meanings of the foreign lexical items. This process is sometimes called neologism, which the Longman Modern English Dictionary (Watson 1976) refers to as 'the use of words or phrases for a new meaning'. 
The main objective of this article is to analyze critically the role played by borrowing in the development of the Sesotho sa Leboa lexicon. The research also analyzes the role played by purism as an impediment to the development of vocabulary in Sesotho sa Leboa.

\section{The role played by borrowing in Sesotho sa Leboa}

Borrowing plays a major role in the development of languages like Sesotho sa Leboa, especially as far as the following is concerned:

- The development of vocabulary.

- Keeping the language up to date with the latest linguistic developments in all the different spheres of life such as, for instance, the scientific and technological terminologies.

- Increase in the volume of the vocabulary through the conversion of foreign lexical items into loan words in Sesotho sa Leboa.

- In a multilingual society, like South Africa, borrowing helps to bridge the lexical and morphological gaps existing between the various African languages. The meanings of the loan lexical items in Sesotho sa Leboa, for instance, will without difficulties be understood by the speakers of other languages. The loan lexical items in many African languages, which are derived from English, will have more or less the same semantic and morphological features, as shown in the following examples:

- morphology: mofolotši (in Sesotho sa Leboa), and mùfùloji (in Ciluba)

- battery: peteri (in Sesotho sa Leboa), and bhatiri (in chiShona)

\section{Defining a loan word}

Mojela (1991: 14) describes a loan word as follows:

A word which has been taken up in the linguistic system of the borrowing language in such a way that it has become part and parcel of the borrowing language.

The loan words in Sesotho sa Leboa conform to its linguistic system. This includes all the phonological, morphological and lexical adaptations of the loan words. For example, the nominal loan words often conform to the nominal class system of Sesotho sa Leboa, e.g.:

peila > dipeila 'axe' > 'axes' (from Afrikaans byl)

galase $>$ digalase 'glass' > 'glasses'

khomphutha > dikhomphutha 'computer' > 'computers' 
However, class prefixes have to be provided in many cases to accommodate nominal loan words, e.g.:

lebotlelo (class 5) 'bottle'

The Sesotho sa Leboa verbal derivational system applies automatically to the newly acquired loan verbs, i.e.:

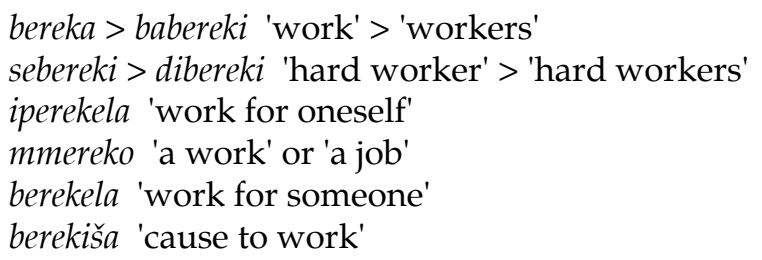

\section{Borrowing and loan words prior to standardization}

Borrowing and the development of loan lexical items prior to the standardization of Sesotho sa Leboa proceeded spontaneously and uninterrupted by common barriers such as linguistic rules, purism and the pressures exerted by the language control and monitoring bodies. Many loan words in most indigenous African languages were formed during the period prior to the commencement of the standardization. The foreign lexical items, derived from languages such as, among others, Afrikaans, Dutch, German, English and the Nguni languages, were used spontaneously by the Sesotho sa Leboa community. There was no controlling or discouraging the use of these foreign lexical items because they helped the indigenous communities to name the new concepts which originated from these foreign cultures. These new lexical items were adopted automatically into the linguistic and phonological system of the indigenous languages. When the standardization of the African languages commenced, the majority of the existing loan lexical items were already in circulation. For instance, at the beginning of the standardization period of Sesotho sa Leboa, most of these previously adopted lexical items were regarded by the majority of the people, including the purists, as indigenous lexical items, since the words were by then incorporated within the linguistic system of Sesotho sa Leboa. Lack of linguistic barriers and puristic approaches during the period prior to the standardization led to an increase in the rate of foreign acquisition, which again resulted in a faster growth of the volume of the Sesotho sa Leboa vocabulary. The following are examples of lexical items acquired during this period, i.e. the period prior to the advent of puristic attitudes and protective linguistic rules in Sesotho sa Leboa:

tšhelete 'money' (Afrikaans geld)

manala 'nails' (Afrikaans naels)

pere 'horse' (Afrikaans perd) 


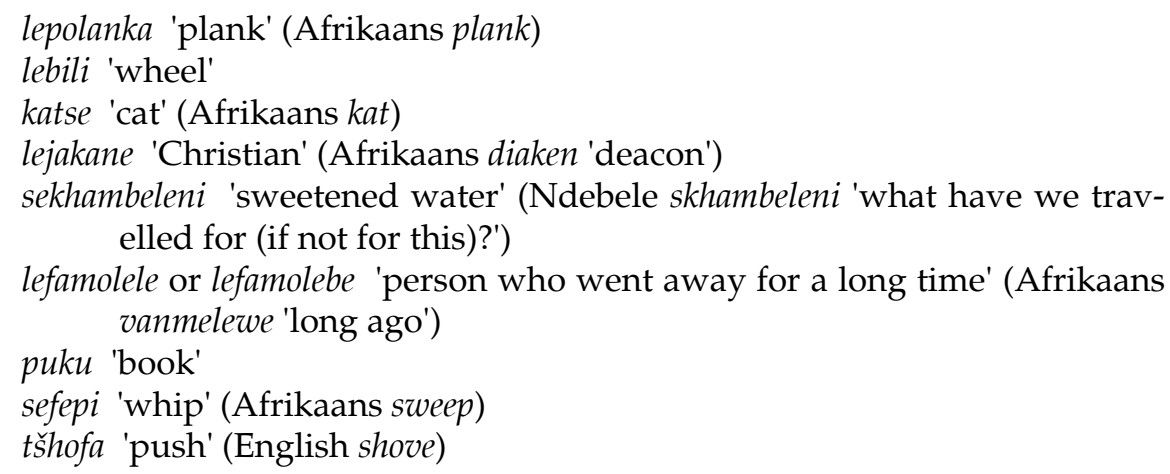

Most language users (and even purists) did not identify the majority of these lexical items as loan words. They just regarded them as forming part and parcel of the indigenous vocabulary of Sesotho sa Leboa. As a result, many loan words originated during this period, with no one questioning issues such as spelling, consistency and violation of rules.

\subsection{Defining purism}

Lexical purism can be defined as a policy of excluding foreign lexical elements from the language so that it can remain 'pure'. The Longman Modern English Dictionary (Watson 1967) describes purism as 'a strict emphasis on purity, especially in language'. This dictionary further defines a purist as:

\footnotetext{
a person who places great emphasis or overemphasis on linguistic purity freedom from foreign words or bastard form. A person who will admit no departures from some chosen method, technique or ideal of perfection.
}

The following are some of the attitudes and opinions of purists with regard to indigenous African languages:

- They disapprove of foreign influence in the language. The foreign elements are regarded as distorting and contaminating the language, instead of developing and empowering it.

- They prefer the language to develop from within and not from without. Preference is given to indirect borrowing as a positive form of foreign acquisition, in the belief that the indigenous languages have sufficient terminology to serve as variants or synonyms for the new concepts which originate within foreign cultures and languages.

- They regard the indigenous languages as self-sufficient, able to survive without foreign influence. 


\subsection{The significance of purism in a language}

The direct result of purism in Sesotho sa Leboa was the narrow and one-sided standardization which led to the neglecting and, thereby, stigmatizing of most of its indigenous dialects. The majority of the scholars and intellectuals who dominated the membership of the Language Boards came from the few dialects spoken in the areas of Gasekhukhune, Maleuskop and the areas around Polokwane, Mokopane and Waterberg. These areas were the first to have missionary activities, mostly German missionaries, who converted Sesotho sa Leboa (especially Sepedi) into written form. Those who served on the Language Boards standardized Sesotho sa Leboa according to their own dialects and neglected most of the dialects in the Lowveld regions, the Northern and the North Western parts of the former Transvaal. These neglected dialects include those like Sepulana, Selobedu, Setlokwa, Sehananwa and Seroka, i.e. those spoken by the majority of the people who were still poorly educated, owing to a lack of missionary activities in these regions. These scholars and intellectuals play a protective role to ensure that the 'inferior' dialects will not have any influence on the standard language, and that standard Sesotho sa Leboa will remain 'pure'. The same methods which were used to exclude the 'stigmatized' dialects from the standard language are now used to discourage the use of the loan lexical items and to exclude most of these lexical items from standardization, on the grounds that there are suitable indigenous Sesotho sa Leboa lexical items to substitute them.

As a result, the influence of purism in a language, especially an underdeveloped language like Sesotho sa Leboa, usually leads to the following:

Very slow growth of the vocabulary of the language: Since most of the new inventions originate in (and evolve from) the highly developed and industrialized countries of the world, there will always be a need to adopt vocabulary from these foreign languages. Unfortunately, however, purism will always thwart this process, retarding the progress of the language.

- Foreign acquisition through coinage: Linguistic coinage, which is the only way to foreign acquisition, obviously leads to widespread ambiguity in the language. Most coined lexical items in Sesotho sa Leboa need to be supplemented by a qualificative to disambiguate them, e.g.:

Loan word: thelefomo 'telephone' (direct borrowing)

Coined word: mogala 'telephone' (indirect borrowing)

The word thelefomo refers only to a telephone, while mogala refers to (a) a string or rope used to tame heifers, (b) a rope, and (c) a telephone. It is therefore ambiguous. The sentence, o swere mogala 'he/she is holding a telephone/rope/string', will consequently not always mean $o$ swere thelefomo 'he/she is holding a telephone'. 
- As a result, the language will not have enough loan lexical items to name the newly acquired concepts which originate from foreign languages.

\section{Conclusion}

With regard to the development of the vocabulary of Sesotho sa Leboa, the most important recommendations are the following:

- While supporting the use of coinage or indirect borrowing as a means of foreign acquisition, the use of direct borrowing, which leads to the adoption of loan words or transliterated lexical items, is also an important and accurate method of creating and developing new lexical items in Sesotho sa Leboa.

- The loan words can be used as synonyms to the coined indigenous lexical items.

- Ill-considered purism in Sesotho sa Leboa, which is mostly applied by the indigenous scholars and intellectuals, should be discouraged, because it is disadvantageous to Sesotho sa Leboa, leading to lexical impoverishment.

In contrast to the coined lexical items which are mostly ambiguous, loan words have single meanings, and as such, it will always be easy to lemmatize unambiguous loan lexical items rather than struggling with polysemous and ambiguous coined lexical items.

\section{References}

Gumperz, J.J. 1968. The Speech Community. Sills, D.L. (Ed.). 1968. International Encyclopedia of the Social Sciences. Volume 9: 381-386. New York: The Macmillan Company/The Free Press.

Higa, M. 1980. Sociolinguistic Aspects of Word-borrowing. Mackey, W.F. and J. Ornstein (Eds.). 1980. Sociolinguistics: Studies in Language Contact: 275-292. The Hague: Mouton.

Mojela, M.V. 1991. Semantic Changes Accompanying Loan Words in the Northern Sotho Lexicon. Unpublished M.A. Thesis. Pretoria: Vista University.

Watson, O. (Ed.). 1976. Longman Modern English Dictionary. Harlow: Longman. 